\title{
Effects of Rootstocks on Horticultural Characteristics of Various Exotic Apple Cultivars in Kashmir Climatic Conditions
}

\author{
J.A. Rather*, F.A. Misgar, G.A. Dar and S.N. Qurashi \\ Division of Fruit Science Sher-e-Kashmir University of Agricultural Sciences \& Technology \\ of Kashmir, Shalimar, Srinagar-19112, India \\ *Corresponding author
}

Keywords

Apple, Dwarf and semi vigrous

rootstocks, Vegetative and horticultural traits

Article Info

Accepted:

20 March 2018

Available Online:

10 April 2018

\section{A B S T R A C T}

This study was aimed to determine the rootstock effect on various horticultural traits like annual extension growth, tree volume, TCSA, fruit weight, fruit volume and yield were significantly affected by rootstocks and recorded maximum vegetative growth in trees on $\mathrm{MM}_{106}$ compared to $\mathrm{M}_{9}$ rootstock during the studies. The vegetative growth also varied significantly among cultivars which are genetically controlled feature in different apple cultivars. Fruits harvested from trees on $\mathrm{MM}_{106}$ were significantly higher in quality parameters like fruit weight, fruit volume and yield compared to those on $\mathbf{M}_{9}$ rootstocks. Different varieties on $\mathrm{MM}_{106}$ rootstock recorded significantly higher yield of 16.55 and $20.19 \mathrm{~kg} /$ tree compared to 13.7 and $18.65 \mathrm{~kg} /$ tree on $\mathrm{M}_{9}$ rootstock during the studies. Results showed that the Vista Bella on the $\mathrm{MM}_{106}$ rootstock had the most mean shoot length of the current year $(39.97 \mathrm{~cm})$, Vista Bella and Mollies Delicious observes highest tree volume $\left(19.22,19.76 \mathrm{~m}^{3}\right)$ and the lowest tree volume $\left(15.01,17.45 \mathrm{~m}^{3}\right)$ was recorded in Cooper IV. Cultivars also had a significant effect on the TCSA and record maximum $\left(78.97\right.$ and $\left.86.68 \mathrm{~cm}^{2}\right)$ in Starkrimson and minimum (59.92 and $60.18 \mathrm{~cm}^{2}$ ) in Vista Bella and Cooper IV respectively during both years of studies. Fruit weight and fruit volume was maximum recorded in Starkrimson $\left(218.04,228.56 \mathrm{~g}\right.$ and $\left.171.36,175.91 \mathrm{~cm}^{3}\right)$ as compared to other cultivars. Among cultivars Vista Bella had maximum yield $\mathrm{kg} / \mathrm{tree}$ (19.60 and $23.58 \mathrm{~kg} /$ tree) and Cooper-IV recorded lowest (7.20 and $12.81 \mathrm{~kg} /$ tree) during the study period.

\section{Introduction}

Trees must be trained and pruned to achieve a manageable uniform size, a balance between growth and regular yield, and to allow good penetration of light and spray to the tree center (Malavolta and Cross, 2009). Most apple scion cultivars grown on their own roots or on seedling rootstocks produce large standard trees of 7-10 $\mathrm{m}$ in height and spread. While as such trees are acceptable in countries where land and labor are very inexpensive, in most apple producing areas of the world some reduction in this natural vigor is desired (Ferree and Warrington, 2003; Ahmad Dadashpour et al., 2012). Dwarf and semi vigrous rootstocks such as $\mathrm{M}_{9}$ reduce $20-30 \%$ tree size compared with seedling rootstock (Fazio and Baldo, 2005). However, the final size of trees grown on $\mathrm{M}_{9}$ will depends greatly 
on the inherent vigor of the scion cultivar, the soil fertility and the management system adopted by the grower (Ferree and Warrington, 2003). Dwarfing rootstocks have become widely acceptable by the industry as a tool for increasing orchard efficiency because they influence the size of tree, yield and planting density per unit area (Barritt et al., 1995). Modern orchards planting systems are based on higher tree densities with a range from 1000 to 6000 trees per hectare and some up to 10000 trees per hectare (Robinson, 2003). However, increasing planting density alone does not increase yield, as planting density and yield are not linearly related and a threshold can be found beyond which a further increase in density may not result in greater yield (Webster, 2001; Hampson et al., 2002).

Clonal dwarfing apple rootstocks control scion growth by the reduction of canopy spread, branches compression and tree height. $\mathbf{M}_{9}$ introduced as a dwarf that induces excellent yield, precocity, efficiency and large fruit size. Although semi-dwarfing $\mathrm{MM}_{106}$ causes high yield efficiency and fruit size can be smaller than $\mathrm{M}_{9}$ (Ferree and Warrington, 2003). More reduction in shoot growth, nods number, trunk diameter, and trunk cross sectional area are inductive effects vegetative dwarfing rootstock in comparison with semi-dwarf or seedling rootstock (Blanco et al., 2008; McAfee and Rom, 2003; Neem et al., 2006). Thus, our objective was to study the influence of vegetative $\mathrm{M}_{9}$ and $\mathrm{MM}_{106}$ rootstocks on reaction of four apple cultivars to achieve large quantities of fruit relative to the amount of wood produce in Kashmir region in India.

\section{Materials and Methods}

Plant material, experimental design, sample collection field experiments were carried out in 2013-14 at an orchard of Central Institute of Temperate Horticulture Srinagar. The experiment was done on twelve year old apple cultivars consist of 'Starkrimson, Cooper IV, Mollies Delicious and Vista Bella' grafted on $\mathrm{M}_{9}$ dwarf and $\mathrm{MM}_{106}$ semi-vigrous rootstock. The trees were planted in 2000 in four replications at a distance $3 \times 1.5$ for $\mathrm{M}_{9}$ and $3 \times 2.5 \mathrm{~m}$ for $\mathrm{MM}_{106}$ rootstock. Twenty four representative trees within each replication and then four uniform branches in the cardinal points of each tree were selected for sampling and data collection. The split plot design based on a randomized complete block (RCBD) with four replications was used for statistical analysis. Analysis of variance (ANOVA) was carried out using the procedure of the OPSTAT software.

\section{Agromorphological characteristics}

In order to measure the shoot growth, average current season growth of four branches in each tree at the end of the seasonal growth was recorded in $\mathrm{cm}$. Also average length of the current seasonal internode was measured in middle of each branch in $\mathrm{cm}$. The average tree volume of each treatment was calculated from height and spread measurements according to the formula given by Westwood (1988). For calculating the trunk cross sectional area (TCSA), trunk circumference about $20 \mathrm{~cm}$ above the graft union was measured with a hand caliper at the end of the growing season and converted to trunk cross sectional area (TCSA) in $\mathrm{cm}^{2}$. Fruit volume was measured by water displacement method and expressed as cubic centimetres (Mazumdar and Majumder, 2003).

\section{Results and Discussion}

\section{Annual extension growth}

Semi vigrous rootstock $\mathrm{MM}_{106}$ recorded maximum (69.25 and $72.08 \mathrm{~cm})$ annual extension growth as compared to (63.75 and $68.16 \mathrm{~cm}$ ) observed in $\mathrm{M}_{9}$ dwarf rootstock during both the years of investigation. 
Similarly, the maximum $(88.83$ and $82.83 \mathrm{~cm})$ AEG was recorded in Vista Bella and minimum (51.33 and $55.16 \mathrm{~cm}$ ) AEG in Cooper IV during both the years of studies. Hirst and Ferree, (1995) also reported that tree growth and development can be markedly influenced by both cultivar and rootstock. Feree and Warrington (2003) reported that the rate of basipetal auxin translocations were less in dwarfing than in invigorating rootstock, also indicated that the ratio of abscisic acid to auxin content were higher in the bark of dwarfing rootstock. Thus, reduction of auxin translocation in $\mathrm{M}_{9}$ bark causes reduction of root growth, subsequently less translocation of gibberellin and cytokinin to scion and finally reduces the vegetative growth (Avery, 1970).

\section{Tree volume}

The highest tree volume (21.05 and $\left.21.57 \mathrm{~m}^{3}\right)$ was observed on $\mathbf{M M}_{106}$ semi vigrous rootstock as compared with the lowest value (13.48 and $15.54 \mathrm{~m}^{3}$ ) observed in $\mathrm{M}_{9}$ dwarf rootstock. Among the cultivars Vista Bella observes highest tree volume and the lowest tree volume was recorded in Cooper IV and Starkrimson respectively (Table 1).

\section{Trunck cross sectional area}

The highest trunck cross sectional area was recorded in MM 106 rootstock (75.35 and $\left.75.07 \mathrm{~cm}^{2}\right)$ as compared to minimum $\mathrm{M}_{9}$ rootstock $\left(57.48\right.$ and $\left.72.10 \mathrm{~cm}^{2}\right)$. Cultivars also had a significant effect on the TCSA and record maximum (78.97 and $86.68 \mathrm{~cm}^{2}$ ) in Starkrimson and minimum (59.92 and $60.18 \mathrm{~cm}^{2}$ ) in Vista Bella and Cooper IV respectively during both years of studies. This increase in TCSA among rootstock significantly influences growth and development of the trees. Further the results are in agreement with those of Dolp and Probsting (1989) who reported that the tree size is controlled by rootstock.

\section{Fruit length diameter ratio}

Fruit L/D ratio was highly influenced by various cultivars, whereas, the rootstocks did not show any significant difference.

$\mathrm{MM}_{106}$ recorded maximum fruit $\mathrm{L} / \mathrm{D}$ ratio (0.86) as compared with lowest value (0.84) recorded in $\mathrm{M}_{9}$ rootstock. However, during next year $\mathrm{M}_{9}$ and $\mathrm{MM}_{106}$ rootstocks did not show any significant difference.

As for the cultivars where concerned, maximum fruit $\mathrm{L} / \mathrm{D}$ ratio $(0.95$ and 0.93$)$ was recorded in Mollies Delicious and Starkrimson as compared with minimum value recorded in Vista Bella (0.75 and 0.89) during both the years of studies. Barritt et al., (1995) observed that the physiological mechanisms by which dwarfing rootstocks affect fruit characteristics like length, diameter and length diameter ratio can be due to the reduction in transport of nutrients and hormones, especially gibberellins across the scion/rootstock union.

Ahmad et al., (2012) also reported that bigger fruit size cultivar has more marketable value than other cultivars although this characteristic is affected by both genetic and environmental factors. $L / D(\geq 1)$ is a criteria for insufficient cell elongation in apple but fruits $\mathrm{L} / \mathrm{D}<1$, probably was due to fruit size is smaller on the most dwarfing rootstock and large with the semi vigorous rootstocks.

\section{Fruit weight}

Among the rootstocks $\mathrm{MM}_{106}$ recorded maximum fruit weight (213.23 and $207.86 \mathrm{~g})$ as compared to $\mathrm{M}_{9}$ rootstock (184.00 and $203.44 \mathrm{~g}$ ) during both the years of studies. Similarly, cultivars significantly affected the fruit weight and recorded maximum (218.04 and $228.56 \mathrm{~g}$ ) in Starkrimson and minimum (171.36 and 175.91g) in Vista Bella during the study. 
Table.1 Rootstock effect on agro morphological characteristics in various exotic cultivars of apple

\begin{tabular}{|c|c|c|c|c|c|c|c|c|c|c|c|c|c|c|c|c|c|c|}
\hline \multirow{4}{*}{$\begin{array}{l}\text { Treatm } \\
\text { ent }\end{array}$} & \multicolumn{6}{|c|}{ Annual extension growth $(\mathrm{cm})$} & \multicolumn{6}{|c|}{ Tree volume $\left(\mathbf{m}^{3}\right)$} & \multicolumn{6}{|c|}{ Tree trunk cross-sectional area $\left(\mathrm{cm}^{2}\right)$} \\
\hline & \multicolumn{3}{|c|}{2013} & \multicolumn{3}{|c|}{2014} & \multicolumn{3}{|c|}{2013} & \multicolumn{3}{|c|}{2014} & \multicolumn{3}{|c|}{2013} & \multicolumn{3}{|c|}{2014} \\
\hline & \multicolumn{2}{|c|}{ Rootstock } & \multirow{2}{*}{ Mean } & \multicolumn{2}{|c|}{ Rootstock } & \multirow[t]{2}{*}{ Mean } & \multicolumn{2}{|c|}{ Rootstock } & \multirow[t]{2}{*}{ Mean } & \multicolumn{2}{|c|}{ Rootstock } & \multirow[t]{2}{*}{ Mean } & \multicolumn{2}{|c|}{ Rootstock } & \multirow[t]{2}{*}{ Mean } & \multicolumn{2}{|c|}{ Rootstock } & \multirow[t]{2}{*}{ Mean } \\
\hline & $\mathrm{M}_{9}$ & $\mathrm{MM}_{106}$ & & $\mathrm{M}_{9}$ & $\mathrm{MM}_{106}$ & & $\mathrm{M}_{9}$ & $\mathrm{MM}_{106}$ & & $\mathrm{M}_{9}$ & $\mathrm{MM}_{106}$ & & $\mathrm{M}_{9}$ & $\mathrm{MM}_{106}$ & & $\mathrm{M}_{9}$ & $\mathrm{MM}_{106}$ & \\
\hline SK & 55.00 & 60.66 & 57.83 & 58.33 & 64.00 & 61.16 & 10.40 & 21.81 & 16.10 & 11.46 & 23.97 & 17.71 & 78.15 & 79.80 & 78.97 & 84.92 & 88.44 & 86.68 \\
\hline C.IV & 50.00 & 52.66 & 51.33 & 55.33 & 55.00 & 55.16 & 10.30 & 19.72 & 15.01 & 13.99 & 20.90 & 17.45 & 44.56 & 78.15 & 61.35 & 47.12 & 73.24 & 60.18 \\
\hline MD & 63.33 & 72.66 & 67.99 & 70.00 & 92.66 & 81.33 & 15.99 & 21.46 & 18.72 & 18.86 & 20.67 & 19.76 & 63.90 & 66.95 & 65.42 & 74.84 & 73.24 & 74.04 \\
\hline$\overline{\text { VB }}$ & 86.66 & 91.00 & 88.83 & 89.00 & 76.66 & 82.83 & 17.26 & 21.19 & 19.22 & 17.86 & 20.73 & 19.30 & 43.33 & 76.51 & 59.92 & 81.52 & 65.39 & 73.45 \\
\hline Mean & 63.75 & 69.25 & & 68.16 & 72.08 & & 13.48 & 21.05 & & 15.54 & 21.57 & & 57.48 & 75.35 & 66.41 & 72.10 & 75.07 & 73.58 \\
\hline \multicolumn{7}{|c|}{$\begin{array}{l}\text { CD }(p \leq 0.05) \\
2013=\text { R 3.89 V 5.50 RXV NS, } \\
\text { 2014= R 2.47 V 3.49 RXV NS } \\
\text { Legend= SK= Starkrimson C.IV= Cooper IV MD= Mollies Delicious VB= Vista } \\
\text { Bella } \\
\text { R= Rootstock, V= variety, }\end{array}$} & \multicolumn{6}{|c|}{$\begin{array}{l}\mathrm{CD}(\mathrm{p} \leq 0.05) \\
2013=\mathrm{R} 0.08 \mathrm{~V} 0.12 \mathrm{RXV} 0.17 \\
2014=\mathrm{R} 1.25 \text { V } 1.77 \text { RXV } 2.50\end{array}$} & \multicolumn{6}{|c|}{$\begin{array}{l}\mathrm{CD}(\mathrm{p} \leq 0.05) \\
2013=\mathrm{R} 0.30 \text { V } 0.43 \text { RXV } 0.61 \\
2014=\text { R } 0.61 \text { V } 0.87 \text { RXV } 1.23\end{array}$} \\
\hline
\end{tabular}

Table.2 Rootstock effect on fruit quality parameters in various exotic cultivars of apple

\begin{tabular}{|c|c|c|c|c|c|c|c|c|c|c|c|c|c|c|c|c|c|c|}
\hline \multirow{4}{*}{$\begin{array}{l}\text { Treat } \\
\text { ment }\end{array}$} & \multicolumn{6}{|c|}{ Fruit length diameter ratio } & \multicolumn{6}{|c|}{ Weight (g) } & \multicolumn{6}{|c|}{ Fruit volume $\left(\mathrm{cm}^{3}\right)$} \\
\hline & \multicolumn{3}{|c|}{2013} & \multicolumn{3}{|c|}{2014} & \multicolumn{3}{|c|}{2013} & \multicolumn{3}{|c|}{2014} & \multicolumn{3}{|c|}{2013} & \multicolumn{3}{|c|}{2014} \\
\hline & \multicolumn{2}{|c|}{ Rootstock } & \multirow[t]{2}{*}{ Mean } & \multicolumn{2}{|c|}{ Rootstock } & \multirow[t]{2}{*}{ Mean } & \multicolumn{2}{|c|}{ Rootstock } & \multirow[t]{2}{*}{ Mean } & \multicolumn{2}{|c|}{ Rootstock } & \multirow[t]{2}{*}{ Mean } & \multicolumn{2}{|c|}{ Rootstock } & \multirow[t]{2}{*}{ Mean } & \multicolumn{2}{|c|}{ Rootstock } & \multirow[t]{2}{*}{ Mean } \\
\hline & $\mathrm{M}_{9}$ & $\mathrm{MM}_{106}$ & & $\mathrm{M}_{9}$ & $\mathrm{MM}_{106}$ & & $\mathrm{M}_{9}$ & $\mathrm{MM}_{106}$ & & $\mathrm{M}_{9}$ & $\mathrm{MM}_{106}$ & & $\mathrm{M}_{9}$ & $\mathrm{MM}_{106}$ & & $\mathrm{M}_{9}$ & $\mathrm{MM}_{106}$ & \\
\hline SK & 0.91 & 0.95 & 0.93 & 0.94 & 0.91 & 0.92 & 211.25 & 224.83 & 218.04 & 215.03 & 242.10 & 228.56 & 187.00 & 198.33 & 192.66 & 206.66 & 221.00 & 213.83 \\
\hline C.IV & 0.87 & 0.93 & 0.90 & 0.90 & 0.90 & 0.90 & 188.63 & 216.16 & 202.40 & 211.18 & 201.93 & 206.55 & 150.66 & 189.00 & 169.83 & 178.00 & 201.00 & 189.50 \\
\hline MID & 0.84 & 0.81 & 0.82 & 0.95 & 0.96 & 0.95 & 170.13 & 235.22 & 202.67 & 211.86 & 211.30 & 211.58 & 145.33 & 207.66 & 176.50 & 201.00 & 205.33 & 203.16 \\
\hline VB & 0.74 & 0.77 & 0.75 & 0.90 & 0.88 & 0.89 & 166.00 & 176.73 & 171.36 & 175.70 & 176.13 & 175.91 & 121.00 & 140.33 & 130.66 & 139.33 & 136.66 & 138.00 \\
\hline Mean & 0.84 & 0.86 & 0.85 & 0.91 & 0.91 & 0.91 & 184.00 & 213.23 & & 203.44 & 207.86 & & 150.99 & 183.83 & & 180.49 & 190.99 & \\
\hline \multicolumn{7}{|c|}{$\begin{array}{l}\text { CD }(p \leq 0.05) \\
2013=\text { R NS V } 0.04 \text { RXV NS } \\
\text { 2014= R NS V 0.03 RXV NS } \\
\text { Legend= SK= Starkrimson C.IV= Cooper IV MID= Mollies Delicious VB= } \\
\text { Vista Bella } \\
\text { R= Rootstock. V= varietv. }\end{array}$} & \multicolumn{6}{|c|}{$\begin{array}{l}C D(p \leq 0.05) \\
\text { 2013= R 5.58 V } 7.89 \text { RXV } 11.12 \\
2014=\text { R NS V } 11.97 \text { RXV } 16.92\end{array}$} & \multicolumn{5}{|c|}{$\begin{array}{l}C D(p \leq 0.05) \\
2013=R 13.57 \text { V } 19.19 \text { RXV } 27.14 \\
2014=\text { R NS V 11.57 RXV 16.36 }\end{array}$} & \\
\hline
\end{tabular}




\section{Int.J.Curr.Microbiol.App.Sci (2018) 7(4): 2341-2348}

Table.3 Rootstock effect on chemical parameters and yield in various exotic cultivars of apple

\begin{tabular}{|c|c|c|c|c|c|c|c|c|c|c|c|c|c|c|c|c|c|c|}
\hline \multirow{4}{*}{$\begin{array}{l}\text { Treat } \\
\text { ment }\end{array}$} & \multicolumn{6}{|c|}{ TSS (B \%) } & \multicolumn{6}{|c|}{ Total sugar (\%) } & \multicolumn{6}{|c|}{ Yield (Kg/tree) } \\
\hline & \multicolumn{3}{|c|}{2013} & \multicolumn{3}{|c|}{2014} & \multicolumn{3}{|c|}{2013} & \multicolumn{3}{|c|}{2014} & \multicolumn{3}{|c|}{2013} & \multicolumn{3}{|c|}{2014} \\
\hline & \multicolumn{2}{|c|}{ Rootstock } & \multirow[t]{2}{*}{ Mean } & \multicolumn{2}{|c|}{ Rootstock } & \multirow[t]{2}{*}{ Mean } & \multicolumn{2}{|c|}{ Rootstock } & \multirow[t]{2}{*}{ Mean } & \multicolumn{2}{|c|}{ Rootstock } & \multirow[t]{2}{*}{ Mean } & \multicolumn{2}{|c|}{ Rootstock } & \multirow[t]{2}{*}{ Mean } & \multicolumn{2}{|c|}{ Rootstock } & \multirow[t]{2}{*}{ Mean } \\
\hline & $\mathrm{M}_{9}$ & $\mathrm{MM}_{106}$ & & $\mathrm{M}_{9}$ & $\mathrm{MM}_{106}$ & & $\mathrm{M}_{9}$ & $\mathrm{MM}_{106}$ & & $\mathrm{M}_{9}$ & $\mathrm{MM}_{106}$ & & $\mathrm{M}_{9}$ & $\mathrm{MM}_{106}$ & & $\mathrm{M}_{9}$ & $\mathrm{MM}_{106}$ & \\
\hline SK & 14.50 & 15.63 & 15.06 & 14.16 & 15.00 & 14.58 & 13.20 & 14.03 & 13.61 & 14.20 & 14.50 & 14.35 & 13.83 & 19.43 & 16.63 & 20.93 & 23.90 & 22.41 \\
\hline C.IV & 13.46 & 13.93 & 13.69 & 12.90 & 13.23 & 13.06 & 10.96 & 11.50 & 11.23 & 11.20 & 12.0 & 11.6 & 8.30 & 6.26 & 7.28 & 15.00 & 10.63 & 12.81 \\
\hline MD & 14.16 & 15.03 & 14.59 & 14.36 & 15.00 & 14.68 & 11.16 & 12.03 & 11.59 & 12.40 & 12.50 & 12.45 & 18.71 & 15.56 & 17.14 & 15.96 & 21.76 & 18.86 \\
\hline VB & 11.96 & 13.56 & 12.76 & 11.36 & 12.63 & 11.99 & 9.70 & 8.23 & 8.96 & 9.36 & 8.96 & 9.16 & 14.33 & 24.93 & 19.63 & 22.70 & 24.46 & 23.58 \\
\hline Mean & 13.52 & 14.53 & 14.02 & 13.19 & 13.96 & 13.57 & 11.25 & 11.44 & & 11.79 & 11.99 & & 13.79 & 16.55 & & 18.65 & 20.19 & \\
\hline $\begin{array}{l}\text { CD (ps } \\
2013= \\
2014= \\
\text { Legen } \\
\text { Bella } \\
\text { R= Ro }\end{array}$ & $\begin{array}{l}5 \mathrm{~V} 1.0 \\
\mathrm{~V} 1.33 \\
=\text { Star } \\
\end{array}$ & $\begin{array}{l}\text { V } 1.50 \\
1.88 \\
\text { son C.IV }\end{array}$ & ooper IV & $=\mathrm{Mol}$ & Delicious & $=$ Vista & \multicolumn{6}{|c|}{$\begin{array}{l}\mathrm{CD}(\mathrm{p} \leq 0.05) \\
2013=\mathrm{R} \text { NS V } 1.32 \mathrm{RXV} \text { NS } \\
2014=\text { R NS V } 1.24 \text { RXV } 1.75\end{array}$} & \multicolumn{6}{|c|}{$\begin{array}{l}C D(p \leq 0.05) \\
2013=R 1.47 \text { V } 2.08 \text { RXV } 2.94 \\
2014=\text { R NS V } 2.55 \text { RXV } 3.60\end{array}$} \\
\hline
\end{tabular}


EL-Sabagh (2012) also reported that as for the effect of rootstocks, it was found that $\mathrm{MM}_{106}$ rootstock increased significantly the means of Anna apple fruit weight, fruit size, fruit diameter and fruit volume as compare to Malus rootstock in both seasons. Groot (1997) observed that the relationship between scion fruit quality and rootstock may be due to function of nutrients.

\section{Fruit volume}

Fruit volume was maximum recorded in $\mathrm{MM}_{106}$ rootstock (183.83 and $190.99 \mathrm{~m}^{3}$ ) and minimum (150.99 and $\left.180.49 \mathrm{~m}^{3}\right)$ was produced in $\mathrm{M}_{9}$ rootstock. Similarly the cultivars significantly affected the fruit volume with maximum (192.66 and $213.83 \mathrm{~m}^{3}$ ) was recorded in Starkrimson and minimum $\left(130.66\right.$ and $\left.138.00 \mathrm{~m}^{3}\right)$ recorded in Vista Bella.

Our results are closely related to Georgiou (2000), and Jaskani, et al., (2006) who observed that rootstocks widely affect the fruit volume and size in citrus. EL. Sabagh (2012) also reported that as for the effect of rootstocks, it was found that $\mathrm{MM}_{106}$ rootstock increased significantly the means of Anna apple fruit volume, fruit size, fruit diameter and fruit weight as compare to Malus rootstock in both seasons (Table 2).

\section{Total soluble solids}

The total soluble solid content of various cultivars of apple showed a significant difference among rootstocks. Whereas Starkrimson produced the maximum TSS (15.06 and $\left.14.58{ }^{\circ} \mathrm{B}\right)$ and Vista Bella produced the lowest TSS (12.76 and 12.63 ${ }^{\circ} \mathrm{B}$ ) during both the years of studies. $\mathrm{MM}_{106}$ rootstock recorded maximum TSS (14.53, $13.96{ }^{\circ} \mathrm{B}$ ) as compared with the lowest value observed in $\mathrm{M}_{9}$ rootstock (13.52 and 13.19 $\left.{ }^{\mathrm{o}} \mathrm{B}\right)$ (Table 3).

\section{Total sugar}

It is clear that on both rootstocks total sugar did not reveal any significant difference, maximum total sugar (11.44 and $11.99 \%$ ) was recorded on $\mathrm{MM}_{106}$ rootstock as compared with minimum $\mathrm{M}_{9}$ rootstock (11.25 and $11.79 \%)$. Among the cultivars Starkrimson observed maximum total sugar (13.61 and $14.35 \%$ ) whereas minimum was recorded in Vista Bella (8.96 and 9.16\%) on both rootstocks during both the years of study. Dolp and Probsting (1989) observed a significant variation on both rootstocks and reported that $\mathrm{MM}_{106}$ rootstock recorded highest total sugar as compared with the lowest value observed in $\mathrm{M}_{9}$ rootstock. The results are in agreement with Orazem et al., (2011) in respect of sugars and acids a balanced sugar to acid ratio in apple fruit could provide sweet but refreshing taste.

\section{Fruit yield}

Fruit yield is of prime concern to orchardists as they grow trees for better yield and good quality fruit. Fruit yield was found to be significantly influenced by rootstocks and cultivars. $\mathrm{MM}_{106}$ rootstock recorded significantly higher yield (16.55 and 20.19 $\mathrm{kg} /$ tree) compared to that on $\mathrm{M}_{9}$ rootstock (13.79 and $18.65 \mathrm{~kg} /$ tree) during the studies respectively, $\mathrm{MM}_{106}$ rootstock produced more number of fruits/ tree, because the vegetative growth being higher. Therefore rate of photosynthesis is higher resulting in higher yield in $\mathrm{MM}_{106}$ rootstock compared to $\mathrm{M}_{9}$.

These results are in agreement with the findings of Path et al., (1989) and Wustcher and Shull (1976) who reported that rootstocks widely affect the yield. Among the cultivars, Vista Bella produced highest fruit yield (19.63 and $23.58 \mathrm{~kg} /$ tree) and Cooper IV produced the lowest yield (7.28 and 12.81 $\mathrm{kg} /$ tree) during the two years respectively, 
which might be due to higher fruit size in the former compare to late.

\section{References}

Ahmad Dadashpour, Mohammad Javad Shakouri and Zahra Fallah Shojaie (2012) Evaluation of growth, yield and fruit characteristics of five apple cultivars on "Gutingen V" system during 2006-2008. Indian J. Sci. Technol. 5 (1). This issue. http://www.indjst.org.

Avery DJ (1970) Effects of fruiting on the growth of apple trees on four rootstock varieties. New Phytologist. 69 (1), 1930.

Barritt BH, Konishi AS and Dilley MA (1995) Intensive orchard management performance of three apple cultivars with 23 dwarfing rootstock during 8 seasons in Washington. Fruit Var. J. 49 (3), 158-170.

Blanco A, Mqta AP, Lasasosa A and Val J (2008) The P16 rootstock inhibits the growth but enhances the fruit quality of 'Jonagored' apples when grown under warm summer conditions. Spanish J. Agric. Res. 6 (3), 412-421.

Dolp CA and Proebsting EL (1989) Root confinement effects growth and physiology of sweet cherry and apple. 50th ASHS Ann. Meeting, Tulsa, Oklahoma, Prog. and Abstract. pp: 99.

$\mathrm{El}=$ Sabagh, A. S., Othman, S. A. and Alabdaly, A. N. 2012. Performance of anna apple cultivar grown on two different rootstocks in response to hydrogen cyanamide winter spraying. World Journal of Agricultural Sciences 8(1): 01-12.

Fazio U and Baldo AM (2005) Placement of apple rootstock cultivars within the Malus germplasm. Plant and Animal Genomes X3 Conference, North Street, Geneva, NY, USA.
Ferree DC and Warrington IJ (2003) Apples: Botany, Production and Uses. CABI Publ.

Ferree DC and Warrington IJ (2003) Apples: Botany, Production and Uses. CABI Publ.

Georgiou, A. 2000. Performance of 'Nova' mandarin on eleven rootstocks in Cyprus. Scientia Horticulturae 84(1-2): 115-126.

Groot, M. J. 1997. FPO-research on economic aspects of rootstock choice. $\mathrm{M}_{9}$ not always the best choice. Fruit let Den Haag 87(19): 18-19.

Hampson CR, Quamm HA and Brownlee RT (2002) Canopy growth, yield and fruit quality of Royal Gala apple trees grown for eight years in five tree training systems. HortScience. 37, 627-631.

Hirst PM and Ferree DC (1995) Effect of rootstock and cultivar on the growth and precocity of young apple tree. J. Amer. Soc. Hort. Sci. 120, 622-634.

Jaskani, M. J., Haider, A., Khan, M. M., Umbreen, S. and Zahoor, H. 2006. Morphological description of three potential citrus rootstocks. Pakistan Journal of Botany 38(2): 311-317.

Malavolta C and Cross J (2009) Guidelines for integrated production of pome fruits. IOBC/wprs Bull. 47, 1-13.

Mazumdar, B. C. and Majumder, K. 2003. Methods on physico-chemical analysis of fruits. Daya Publishing House. Delhi.

McAfee JD and Rom CR (2003) Evaluation of size- Controling apple rootstock for high density 'Gala' apple orchards in Arkanass Horticultural studies. Department of Horticulture, University of Arkanass. pp: 21-23.

Neem U, Univer $\mathrm{T}$ and Tiirma K (2006) Effect of five rootstocks on growth and Yield of four apple cultivars in Young orchard. Scientific works of the Lithuanian Institute of Horticulture and 
Lithuanian University of Agriculture. 25 (3), 192-198.

Orazem, P., Stampar, F. and Hudina, M. 2011. Quality analysis of 'Redhaven' peach fruit grafted on 11 rootstocks of different genetic origin in a replant soil. Food Chemistry 124(4): 1691-1698.

Path, B. S., Hulmani, N. C. and Nalowadi, U. G. 1989. Leaf macro-nutrient composition of Tahiti lime as influenced by different rootstocks. Journal of Maharashtra Agricultural Universities, India 14(3): 359-360.

Robinson TL (2003) Apple-orchard planting system. In: Apples (eds.), Ferree DC and Warrington IJ (Eds), Cabi Publ., Wallingford, UK. pp: 345-407.

Webster AD (2001) Rootstocks and temperate fruit crops: current uses, future potenial and alternative. Acta Hort. 557, 25-34.

Westwood, M. N. 1988. Temperate Zone Pomology. $2^{\text {nd }}$ edition. Timber Press Portland, Oregon pp. 428.

Wutscher, H. K. and Shull, A. V. 1976. Performance of Marrs Early orange on 11 rootstocks in South Texas. Journal of American Society for Horticultural Science 101(2): 158-161.

\section{How to cite this article:}

Rather, J.A., F.A. Misgar, G.A. Dar and Qurashi, S.N. 2018. Effects of Rootstocks on Horticultural Characteristics of Various Exotic Apple Cultivars in Kashmir Climatic Conditions. Int.J.Curr.Microbiol.App.Sci. 7(04): 2341-2348.

doi: https://doi.org/10.20546/ijcmas.2018.704.268 